\title{
Walnut (Juglans regia L.) micropropagation
}

\author{
M.A. Revilla, J. Majada and R. Rodriguez
}

Lab. Fisiologia Vegetal, Universidad de Oviedo, España

\section{Introduction}

One of the main problems involved in walnut micropropagation by tissue culture techniques is the low rate of multiplication. This can be due to the slow growth of the regenerated shoots leading to extended culture periods and thus resulting in the appearance of latent contamination in the culture (Somers et al., 1982; Driver and Kuniyuki, 1984; McGranahan et al., 1986). To overcome this problem, we have tried to culture nodal segments from embryonic and juvenile material in a double-phase system, which has been shown to increase production of axillary shoots (Viseur, 1985), and to include in the culture medium antibiotic mixtures to prevent bacterial contamination (Phillips et al., 1981; Young et al., 1984). This research is being conducted to optimize the micropropagation techniques for walnut (Juglans regia L.).

\section{Materials and Methods}

Experiments have been made with embryonic and juvenile nodal segments of walnut. Embryonic axes were excised from seeds previously imbibed for $24 \mathrm{~h}$ in water and disinfect- ed for $5 \mathrm{~min}$ in $0.5 \% \mathrm{NaClO}$ solution followed by $5 \mathrm{~min}$ in $75 \%$ ethanol and 3 rinses in sterile distilled water. Embryonic axes were cultured for 8 wk before excising the nodal segments.

Juvenile material was taken from $2-3$ mo old plantlets germinated under greenhouse conditions that had been sprayed every $15 \mathrm{~d}$ with a solution of $0.04 \mathrm{~g} / \mathrm{l}$ kasugamicin (Lainco), $0.97 \mathrm{~g} / \mathrm{l}$ zineb (Agrocros) and $0.38 \mathrm{~g} / \mathrm{l}$ cupric oxychloride (Agrocros). Before taking the explants from the juvenile material, the plantlets were sprayed 2 or 3 times, every $5 \mathrm{~d}$, with a solution of $100 \mathrm{mg} / \mathrm{l}$ BAP (benzylaminopurine) and $50 \mathrm{mg} / \mathrm{G} \mathrm{GA}$ (gibberellin) (McGranahan et al., 1988) to induce vigorous growth.

The medium used was MS (Murashige and Skoog, 1962), supplemented with $30 \%$ sucrose, $0.7 \%$ agar and different combinations of BAP (1-5 mg/l), IBA (indole butyric acid, $0.1 \mathrm{mg} /$ ). IAA (indole acetic acid, $0.05 \mathrm{mg} / \mathrm{l}$ ) and $\mathrm{GA}_{3}$ $(0.1-1 \mathrm{mg} / \mathrm{l})$. The culture conditions were $16 \mathrm{~h}$ photoperiod and $25^{\circ} \mathrm{C}$. To decrease explant exudation, they were transferred onto fresh medium 1, 3, 5 and $8 \mathrm{~d}$ after culture (Driver and Kuniyuki, 1984; McGranahan et al., 1988). For double-phase culture, sterile liquid medium was poured over explants after their transfer onto the solidified medium. The liquid phase always covered the solid medium surface.

Rooting was initiated by dipping the shoot base into the liquid medium containing IBA (2 $\mathrm{mg} / \mathrm{l}$ ) for $24 \mathrm{~h}$ and transferring it onto solidified medium containing $1 \%$ activated charcoal.

The addition of some antibiotic mixtures to the culture medium allowed the recovery of a high percentage of contaminated explants. The levels of antibiotics tested were as follows: cefotaxim 25-75 mg/l, tetracycline $25 \mathrm{mg} / \mathrm{l}$, 
rifampicin $6 \mathrm{mg} / \mathrm{l}$, streptomycin 1-2 mg/l, ampicillin $25 \mathrm{mg} / \mathrm{l}$. Antibiotic solutions were filter sterilized.

\section{Results and Discussion}

\section{Micropropagation}

The best growth regulator combinations for micropropagation of $\mathrm{J}$. regia $\mathrm{L}$. from nodal segments of embryonic or juvenile material were $1.0 \mathrm{mg} / \mathrm{BAP}$ and $0.1 \mathrm{mg} / \mathrm{l}$ IBA. The same results were shown for Juglans nigra (Somers et al., 1982) and Paradox (Driver and Kuniyuki, 1984). Higher BAP concentrations, for short culture periods, produced morphological modifications in leaves and shoots, and finally induced vitrification. The application of $0.1 \mathrm{mg} / \mathrm{GA} \mathrm{GA}_{3}$ induced greater elongation in the embryonary shoots but had no effect on the juvenile shoots.

The establishment of the explants in double-phase cultures increased the micropropagation rate for both types of plant material (Table 1). Similar results were observed for juvenile material when the plantlets in the greenhouse were stimulated with growth regulator solutions. Presumably, the use of both treatments, double-phase and plant growth stimulation, will improve the proliferation rate in walnut.

Sixty percent of the shoots regenerated from embryonic material produced roots. Similar rooting conditions were used by Meynier (1985) for hybrid walnut.

\section{Effect of antibiotics on shoot cultures}

The pretreatments given to the plant material together with the surface sterilization of the explants allowed the recovery, after $15 \mathrm{~d}$ of culture, of $85 \%$ of the explants. However, latent endogenous contamination appeared after 1 or 2 mo of culture resulting in only $5 \%$ final recovery of the explants.

In an attempt to solve this problem, antibiotic mixtures were added to the initial culture medium or to the fresh medium used for transfers.

in the first case, the addition of cefotaxim $(25 \mathrm{mg} / \mathrm{l})$, tetracycline $(25 \mathrm{mg} / \mathrm{l})$, rifampicin $(6 \mathrm{mg} / \mathrm{l})$ and streptomycin $(2 \mathrm{mg} / \mathrm{l})$ (mixture A) allowed the recovery, after 9 wk of culture, of $50 \%$ of the explants. The use of cefotaxim $(25 \mathrm{mg} / \mathrm{l})$, tetracycline (25 mg/l) and ampicillin (25 mg/l) (mixture B) reduced the recovery to $38 \%$. Higher concentrations of cefotaxim induced necrosis and death of all the explants.

Table I. Increased rate and number, after 6 wk in clifferent culture conditions, of regenerated shoots from juvenile nodal segments of walnut (Juglans regia L.).

\begin{tabular}{lll}
\hline Culture condition & $\begin{array}{l}\text { Shoot increase } \\
\text { rate }(\mathrm{cm})\end{array}$ & $\begin{array}{l}\text { Shoot } \\
\text { number }\end{array}$ \\
\hline $\begin{array}{l}\text { Control: solid MS + } \\
(1 \mathrm{mg} / \mathrm{BAP}+0.1 \mathrm{mg} / \mathrm{IBA})\end{array}$ & 0.78 & 1.02 \\
$\begin{array}{c}\text { Control + stimulation with } \\
\text { growth regulator solutions }\end{array}$ & 1.36 & 1.81 \\
Double-phase system & 1.3 & 1.4 \\
\hline
\end{tabular}


Explants transferred after 12 wk of culture to a medium without antibiotics showed new growth of bacterial contamination. Therefore, the bacteriostatic effect predominated over the bactericidal one. No morphological differences were observed between control and antibiotic-treated explants.

Experiments made with contaminated explants, already established in a medium without antibiotics, showed that, when these were subcultured in fresh medium with antibiotics (mixture A), $60 \%$ of the explants could be recovered. In walnut, as in other woody species, such as apple, rhododendron and Douglas fir, the introduction of antibiotics into the medium prevents bacterial contamination (Young et al., 1984).

From this research, it can be concluded that the conditions under which the source plant is grown and the treatments given to the explant in culture are important for success in walnut micropropagation. We expect that the combined actions of the phytosanitary treatment of the plants in the greenhouse or in the field, the application of growth regulator solutions, the culture of explants in a double-phase system and the addition of antibiotics, will greatly aid the establishment of an efficient micropropagation method from selected mature walnut trees.

\section{References}

Driver J.A. \& Kuniyuki A.H. (1984) In vitro propagation of Paradox walnut Juglans hindsii $x$ Juglans regia rootstock. HortScience 19, 507 509

McGranahan G.H., Leslie C.A. \& Driver J.A. (1988) In vitro propagation of mature Persian wainut cultivars. HortScience 23, 220

McGranahan G.H., Tuleke W., Arulsekar S. \& Hansen J.J. (1986) Intergeneric hybridization in the Juglandaceae: Pterocarya $s p \times$ Juglans regia. J. Am. Soc. Hortic. Sci. 111, 627-630

Meynier V. (1985) Mise en culture in vitro de méristèmes de noyers hybrides. C.R. Acad. Sci. Paris Sér. III 301, 261-264

Murashige T. \& Skoog F. (1962) A revised medium for rapid growth and bioassays with tobacco tissue cultures. Physiol. Plant. 15, 473497

Phillips R., Arnott S.M. \& Kaplan S.E. (1981) Antibiotics in plant tissue culture: rifampicin effectively controls bacterial contaminations without affecting the growth of short term explant cultures of Helianthus tuberosus. Plant Sci. Lett. 21, 235-240

Somers P.W., Van Sambeek J.W., Preece J.E., Gaffney G. \& Myers O. (1982) In vitro micropropagation of black walnut. Proc. 7th North Am. For. Biol. University of Kentucky Press, Lexington, pp. 224-230

Viseur J. (1985) Micropropagation of pear, Pyrus communis L., in a double-phase culture medium. Acta Hortic. 212, 117-124

Young P.M., Hutchins A.S. \& Canfield M.L. (1984) Use of antibiotics to control bacteria in shoot cultures of woody plants. Plant. Sci. Lett. 34, 203-209 